\title{
Innovative Pedagogy in Experimental Teaching \& Learning
}

\author{
Jaya Majumder \\ DPS Modern Indian School, Doha, Qatar.
}

\begin{abstract}
To be a successful and good teacher, a teacher should keep adapting various methods and technology. A good teacher keeps experimenting and extends a flexible platform to scaffold her students. The teacher never forgets to incorporate values so that the students will be motivated towards self-determined learning. She should ensure that the students are engaged in various activities via flip classroom. She should know the usage and application of technology to support and enhance Students' skills and make learning more interesting and interactive. She should be ready to adapt to changes as per the need of the learning process. For this she should practice project based, researched based, activity based learning. She should even incorporate art in teaching methodology to create versatile and happy place.
\end{abstract}

Keyword: Innovative Pedagogy, Experimental, learning 